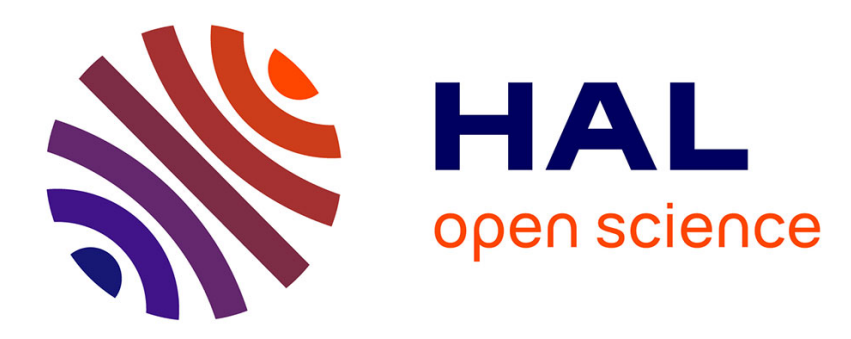

\title{
The Profit-Investment-Unemployment nexus and Capacity Utilization in a Stock-Flow Consistent Model \\ Jean-Bernard Chatelain
}

\section{To cite this version:}

Jean-Bernard Chatelain. The Profit-Investment-Unemployment nexus and Capacity Utilization in a Stock-Flow Consistent Model. Metroeconomica, 2010, 61 (3), pp.454-472. 10.1111/j.1467999X.2009.04074.x . hal-00645155

\section{HAL Id: hal-00645155 \\ https://hal.science/hal-00645155}

Submitted on 26 Nov 2011

HAL is a multi-disciplinary open access archive for the deposit and dissemination of scientific research documents, whether they are published or not. The documents may come from teaching and research institutions in France or abroad, or from public or private research centers.
L'archive ouverte pluridisciplinaire HAL, est destinée au dépôt et à la diffusion de documents scientifiques de niveau recherche, publiés ou non, émanant des établissements d'enseignement et de recherche français ou étrangers, des laboratoires publics ou privés. 


\title{
The Profit-Investment-Unemployment Nexus and Capacity Utilization in a Stock-Flow Consistent Model
}

\author{
Jean-Bernard Chatelain ${ }^{\text {* }}$ \\ Preprint
}

\begin{abstract}
This paper studies under which conditions the share of profit in value added, financial constraints on investment and capital shortage may foster unemployment and may limit the growth of capital and/or the growth of aggregate demand, in a stock-flow consistent model. The efficiency of demand side versus supply side economic policies (decrease of the real interest rate and/or of the real wage, increase of the leverage ceiling constraint) depends on capital shortage and credit rationing, which are not necessarily simultaneous due to the effects of investment on aggregate demand and supply.
\end{abstract}

JEL classification number: E12, E17, E60.

Keywords: Unemployment, Capital Shortage, Credit Rationing, Macroeconomic Policy.

\section{Introduction}

This paper proposes a stock-flow consistent model in order to model European unemployment, investment and distribution issues. Alexiou and Pitelis (2003) and Arestis, Baddeley and Sawyer (2007) analysis and empirical findings suggest that "one of the potential factors behind the high and persistent European unemployment is insufficient growth of capital stock and inadequate aggregate demand" (see also Alexiou [2001]).

${ }^{*}$ CES, University Paris 1 Panthéon Sorbonne, Paris School of Economics and Cepremap. Corresponding address: Centre d'Economie de la Sorbonne, 106/112 Boulevard de l'Hôpital 75647 Paris Cedex 13, France. E-mail: jean-bernard.chatelain@univ-paris1.fr

I wish to thank two anonymous referees and Neri Salvadori for their very helpful comments and suggestions. 
These findings suggest that unemployment is a macro-economic phenomenon, which is not only related to micro-economic characteristics of the labor markets, such as the existence of a minimal wage, unions bargaining power and various kind of mismatches (poor education of low skilled workers, location and so on). Coincidentally, Treeck (2008) observes that accumulation has generally been declining while profit shares and real interest rates have shown a tendency to rise for some important OECD countries since the early 1980s. During the last two decades in Europe, several shocks of high real interest rates have increased bankruptcy risk, so that a large number of firms were likely to face financial constraints with lasting effects on aggregate investment. As well, several shocks related to a relative decrease of public expenditures were observed due to budget constraints in Europe (for example, the defense of the exchange rate mechanism, Maastricht criteria and the Stability and Growth Pact).

The stock-flow consistent models approach is one of the most active areas of research in post-keynesian and heterodox macroeconomics (see Lavoie and Godley (20012); Dos Santos and Zezza (2004, 2006, 2008), Taylor (2004); Dos Santos (2005, 2006); Foley and Taylor (2006); Godley and Lavoie (2007); Le Héron and Mouakil (2008) among many others; see Dos Santos (2006) for a detailed discussion of these authors contributions). The stock-flow consistent models deals with credit and real-financial interaction in a dynamic framework.

The paper proposes a stock flow consistent model of the growth of output and capital, profit rates, debt, and capacity utilization ratios, using simulations in which a growing economy is assumed to be shocked by a rise in interest rates or a fall in public expenditures. The model is based on the accounting flow of funds constraint, when firms may face credit rationing and adjust their degree of capacity utilization, so that it definitely avoids dynamically miscalculated balance sheets. Related papers are for example Villa (2004) and Hein (2007).

This paper focuses on the effects of credit rationing on the growth of both aggregate supply and aggregate demand following those shocks. First, credit rationing implies that the growth of internal equity determines a financial frontier limiting the growth of capital (Lavoie (2004), p. 39). Under certain circumstances, this financial growth frontier may be lower than the warranted growth rate, which may cause a growth of unemployment due to capital shortage. Second, investment is itself a component of aggregate demand. In the short run, the sensitivity of aggregate demand with respect to changes of investment is higher than the sensitivity of aggregate supply. In other words, a capital shortage is not always simultaneous with financial constraints on investment. The simulations mimic some of the swings related to output, unemployment, capacity utilization, investment and the rate of profit observed in Europe during the last decades.

This paper provides a detailed account of the fine tuning of macroeconomic policies depending on the prevalence of capital shortage and/or financial constraints in the economy. The discussion is on demand side versus "financial supply side" policies able to shift the financial frontier of the capital growth and related to a fall of real 
interest rate or of real wage or a rise of the leverage ceiling.

This paper is organized as follows. In section 2 are presented the accounting structure of the model, the behavioural equations of agents and the way to solve the model. Section 3 presents the simulations following a rise of the real interest rate. Section 4 presents the simulations following a decrease of public expenditures. Section 5 concludes.

\section{The model}

\subsection{The Accounting Structure of the Model}

The economy assumed here has households, capitalists owning firms equity, firms which produce a single good with price taken as numeraire, banks and a government sector. The aggregated assets and liabilities of these institutional sectors are presented in table 1 and their variations in table 2 below.

Table 1: Aggregate Balance Sheets of Institutional Sectors

\begin{tabular}{|l|l|l|l|l|l|l|}
\hline & Households & Banks & Capitalists & Firms & Govt & Total \\
\hline Government Bonds & $+B^{g}$ & & & & $-B^{g}$ & \\
\hline Deposits & $+B$ & $-B$ & & & & \\
\hline Credit & & $+B$ & & $-B$ & & \\
\hline Equity & & & $+E$ & $-E$ & & \\
\hline Capital Goods & & & & $+K$ & & $+K$ \\
\hline Total: Net Worth & $=B+B^{g}$ & $=0$ & $=E$ & $=0$ & $=-B^{g}$ & $=K$ \\
\hline
\end{tabular}

Table 2: Aggregate Variation of Balance Sheets of Institutional Sectors $(\Delta X=$ $\left.X_{t}-X_{t-1}\right)$.

\begin{tabular}{|l|l|l|l|l|l|l|}
\hline & Households & Banks & Capitalists & Firms & Govt & Total \\
\hline Government Bonds & $+\Delta B^{g}$ & & & & $-\Delta B^{g}$ & \\
\hline Deposits & $+\Delta B$ & $-\Delta B$ & & & & \\
\hline Credit & & $+\Delta B$ & & $-\Delta B$ & & \\
\hline Equity & & & $+\Delta E$ & $-\Delta E$ & & \\
\hline Capital Goods & & & & $+\Delta K$ & & $+\Delta K$ \\
\hline Total: Savings & $=\Delta B+\Delta B^{g}$ & $=0$ & $=\Delta E$ & $=0$ & $=-\Delta B^{g}$ & $=\Delta K$ \\
\hline
\end{tabular}

Households are assumed to keep their wealth in the form of government bonds $B^{g}$ with a yield to maturity of $r_{0}$ and of bank deposits $B$ with an interest rate $r_{t}$ equal to the interest rate on banks' credit to firms. "Pure capitalists" own firms' equity $E$, with the rate of return on equity $\Delta E / E_{t-1}$. Government is in debt $\left(B^{g}>0\right)$. Banks lend an amount of credit equal to deposits $B$ and do not have profits to distribute: their net worth is equal to zero. Firms finances their capital $K$ with equity $E$ and banks' credit $B$. The relative price of equity and of capital with respect to output price are normalized to unity, so that the model focuses on real terms. Table 3 presents the 
transaction matrix:

Table 3: Transaction matrix.

\begin{tabular}{|l|l|l|l|l|}
\hline & Households-Banks & Firms-Capitalists & Govt & Total \\
\hline Consumption & $-C_{t}$ & $C_{t}$ & & 0 \\
\hline Government Expenditures & & $G_{t}$ & $-G_{t}$ & 0 \\
\hline Investment & & $I_{t}=\Delta K+\delta K_{t-1}$ & & $I_{t}$ \\
\hline Wages & $W_{t} L_{t}$ & $-W_{t} L_{t}$ & & 0 \\
\hline Depreciation & & $-\delta K_{t-1}$ & & $-\delta K_{t-1}$ \\
\hline Interest Credit & $r_{t-1} B_{t-1}$ & $-r_{t-1} B_{t-1}$ & & 0 \\
\hline Interest Bonds & $r_{0} B_{t-1}^{g}$ & & $-r_{0} B_{t-1}^{g}$ & 0 \\
\hline Total: Savings & $=\Delta B^{g}+\Delta B$ & $=\Delta E$ & $=-\Delta B^{g}$ & $=\Delta K$ \\
\hline
\end{tabular}

Households consumption is $C_{t}$. Households income consists of wage earnings with employed labour $L_{t}$ receiving a real wage $W_{t}$, and of the interest payments on deposits and on government bills. Households savings (income less consumption) are invested in the flows of deposits and government bonds (table 3, column 2). Government public expenditures are $G_{t}$ and are financed by new issues of government bonds $\Delta B^{g}$ net of interest payments of last period bonds $r_{0} B_{t-1}^{g}$ (table 3, column 4). In table 3 , column 3 , firms value added $Y_{t}$ is equal to the sum of consumption $C_{t}$, public expenditures $G_{t}$ and investment $I_{t}$, which includes the replacement of depreciated capital, with a depreciation rate $\delta$. Then, value added is distributed in wage income, capital depreciation, interest payment for banks loans and retained profits $E_{t}-E_{t-1}=$ $Y_{t}-W_{t} L_{t}-r_{t-1} B_{t-1}-\delta K_{t-1}$.

In table 3 , bottom line and table 2 , firms' column, firms finance the variation of capital net of capital depreciation using $\Delta K$ with new loans $\Delta B$ and retained profits $\Delta E$. The key novel consequence of taking into account Wood's [1975] financial frontier (or credit constraint) in the stock flow consistent approach is that the firms flow of fund constraint determines investment when the credit constraint is binding. This result remains valid when one assumes that at most a fixed proportion of capital is financed by new share issues and that at least a fixed proportion of profits is received as dividends and consumed by capitalists. For simplicity, the new share issue ceiling and the dividend floor are set to zero (the capitalists's savings rate is equal to unity, but it could be arbitrarily fixed at a lower level). The alternative assumption leading to qualitatively different model than Wood's financial frontier is that new share issues are an unlimited variable proportion of capital which is always able to offset any credit constraint from the banks and any size of losses by the firm, so that financial constraint are never binding and firms never go bankrupt.

The following sections details assumptions first regarding to technology and the labour market, second to the consumption function and public expenditures, third to banks behaviour, and fourth to firms investment. 


\subsection{Production Function, Capacity Utilization and the Labour Market}

The firms decide on capital and on the capacity of production, on labor, prices and wages. Their technology is Leontieff, including a gestation lag for building capacities $Y_{t}^{c}$ out of capital $K_{t-1}$ so that: $Y_{t}^{c}=\frac{1}{k} K_{t-1}$ with a capital/output ratio $k>0$. Aggregate demand $Y_{t}$ may be lower than capacity: $Y_{t}=Y_{t}^{c} C U_{t}$, where the capacity utilization rate is defined as demand divided by capacity: $C U_{t}=\min \left(\frac{Y_{t}^{d}}{Y_{t}^{c}}, 1\right)$. A sluggish adjustment of prices is described in a subsequent paragraph.

The firm hires labor knowing output demand in the short run, so that labor demand depends on the capacity utilization rate: $L_{t}^{d}=\frac{1}{q} Y_{t}^{c} C U_{t}$, with a labour productivity parameter $q>0$. Households labor supply is inelastic and grows at a warranted growth rate $n \geq 0, L_{t}^{s}=L_{0}^{s}(1+n)^{t}$. Employed labor is $L=\min \left(L_{t}^{d}, L_{t}^{s}\right)$. The unemployment rate depends on capacity utilization due to labor demand: $U R_{t}=\min \left(1-\frac{1}{q} \frac{Y_{t}^{c} C U_{t}}{L_{t}^{s}}, 0\right)$.

Prices and nominal wages adjusts slowly when facing the gaps between demand and supply on the labour market and on the goods market. The ratio of these two relations is linearized in order to get the dependance of the real wage $w_{t}$ on the tensions between demand and supply on the labour market and on the goods markets:

$$
w_{t}=w_{0}-a_{1} U R_{t}-a_{2}\left(\frac{Y_{t}^{d}}{Y_{t}^{c}}-1\right)
$$

Prices adjust faster than nominal wages in the short run if: $a_{2}>a_{1} \geq 0$.

\subsection{Consumption and Public Expenditures}

Autonomous public expenditures net of the interest payment on government bonds are supposed to grow at the warranted growth rate $n$ :

$$
G_{t}=(1+n) G_{t-1}
$$

According to table 3, column 3, government expenditures are financed by new issues of government bonds net of the interest payment with an exogenous yield to maturity $r_{0}$ :

$$
G_{t}=B_{t}^{g}-B_{t-1}^{g}-r_{0} B_{t-1}^{g}=\left(\frac{n}{1+n}\right) B_{t}^{g}-\left(\frac{r_{0}}{1+n}\right) B_{t}^{g}
$$

The second equality takes into account that public expenditures are growing exogenously. The stock of public debt $B_{t}^{g}$ and the new issues of government bonds $B_{t}^{g}-B_{t-1}^{g}$ are linear functions of public expenditures $G_{t}$, which are growing at the warranted growth rate $n$. Hence, there is a fixed supply of new government bonds at a given date $t$.

The consumption function of households aggregated with pure capitalists (as in national accounts) is described by a Keynesian fixed constant propensity to consume 
$c$ and an auto-regressive term related to the permanent income hypothesis:

$$
C_{t+1}=b C_{t}+c Y_{t+1}=c \sum_{k=0}^{k=t-1} b^{k} Y_{t-k}^{c} C U_{t-k}+b^{t-1} C_{0}
$$

with $0 \leq b<1$ and $0<c<1$. The auto-regressive term $b$ dampens shocks and slows down the adjustment process. Expectations are adaptative: the informations on forward income $Y_{t+1}$ which are not based on the past are not taken into account by households. Because households consumption and savings depend on total income $Y_{t+1}$ (the sum of wages and of the income of capital, including firms profits) and not specifically on the substitution effect of the interest rate, the model differs from the classical loanable funds theory of interest.

The allocation of savings is as follows. Capitalists have a saving rate of profit equal to unity (table 3, column 2). Households first invest their savings in the fixed supply of risk free new government bonds on date $t$, and then in banks new credit to firms (table 3, column 1). New credit is determined by the equality between the ex-ante aggregate savings curve and the ex-ante investment and public expenditures curve (see the section "solving the model"):

$$
Y_{t}-C_{t}=G_{t}+I_{t}
$$

\subsection{Banks credit supply}

Banks collect deposits and provide credit to firms, facing the interest rate on government bonds as an opportunity cost. The credit supply is such that the interest rate is the sum of the interest rate on government bonds $r_{0}$ and of a credit default risk premium. This risk premium increases with the firm leverage measured by the debt/capital ratio $x_{t}=B_{t} / K_{t}$, when this ratio is between a minimal level $x_{\min } \geq 0$ (a low level of debt over total assets, eventually equal to zero, implies that the probability of bankruptcy is equal to zero) and a maximal level $x_{\max }<1$ strictly below unity (the debt/capital ratio $x_{\max }$ implies that the probability of bankruptcy is equal to unity):

$$
r=r_{0}+\phi \cdot\left(\frac{x-x_{\min }}{x_{\max }-x_{\min }}\right)
$$

Banks ration credit when the firm leverage attains a maximal level $x_{\max }<1$ corresponding to the maximal rate $r_{\max }=r_{0}+\phi$. The sensitivity parameter of the default risk premium to leverage is denoted $\phi$ : it is equal to the largest credit default risk premium, in the credit rationing case.

\subsection{Investment}

The growth of capital depends on whether the firm faces credit rationing or not: 


$$
g_{t+1}^{K}=\frac{I_{t+1}}{K_{t}}-\delta=\min \left(n+a\left(\frac{Y_{t+1}^{d}}{Y_{t+1}^{c}}-1\right), \frac{\pi_{t}-r_{t} x_{t}+\left(x_{\max }-x_{t}\right)}{1-x_{\max }}\right)
$$

Using two regimes allows to do a synthesis between the two post-keynesian approaches:

- In the first regime, investment demand gradually adjusts to stabilize capacity utilization (Shaikh (2009), Skott (2008)). The left hand side of the minimum corresponds to the case where the firm is not constrained. For simplicity, the growth of capital is assumed to be equal to the warranted growth rate (this assumption allows a steady state without a growing unemployment) plus a term correcting the short run tensions on the goods market (excess demand or excess supply) with an adjustment delay measured by the coefficient $a$ (a Penrose effect).

- In the second regime, Wood's (1975) financial frontier limits investment (Lavoie (2004)). The right hand side of the minimum corresponds to a consistent stock flow relation when the firm debt/capital ratio is limited to $x_{\max }$ by lenders. The flow of funds constraint where investment is financed by new debt and retained earnings can be written as a relation between the growth of capital and the debt/capital ratio on date $t$ and date $t+1$ :

$$
\begin{aligned}
K_{t+1}-K_{t} & =I_{t+1}-\delta K_{t}=B_{t+1}-B_{t}+\underbrace{Y_{t+1}\left(1-\frac{w_{t+1}}{q}\right)-\delta K_{t}-r_{t} B_{t}}_{=E_{t+1}-E_{t}} \\
& \Rightarrow \frac{K_{t+1}-K_{t}}{K_{t}}=\frac{I_{t+1}}{K_{t}}-\delta=\frac{\pi_{t}-r_{t} x_{t}+x_{t+1}-x_{t}}{1-x_{t+1}}
\end{aligned}
$$

where $x_{t}$ is the debt/capital ratio, $\pi_{t}+\delta$ is the profit rate before the depreciation of capital and $\pi_{t}$ is the profit rate after the depreciation of capital:

$$
\pi_{t}+\delta=\left(1-\frac{w_{t+1}}{q}\right) \frac{Y_{t+1}}{K_{t}}=\left(1-\frac{w_{t+1}}{q}\right) \frac{Y_{t+1}^{c}}{K_{t}} C U_{t+1}=\left(1-\frac{w_{t+1}}{q}\right) \frac{1}{k} C U_{t+1}
$$

A more detailed framework shows that the price and mark-up behaviour may depend on leverage when there is credit rationing, which in turn modifies the capacity utilization rate (Chatelain [2001]). The capital growth financial frontier is obtained when the leverage constraint is binding: $x_{t+1}=x_{\max }$. The growth of capital is equal to the growth of debt and to the growth of internal equity. The growth of internal equity is equal the return on equity times the saving rate of profits by capitalists, which is here assumed to be equal to unity. A stock constraint on the debt/capital ratio implies a flow constraint on the growth of capital, where the profit rate determines financially constrained investment. If the firm is financially constrained on date $t+1$ and on date 
$t\left(x_{t}=x_{\max }\right)$, the growth rate of capital is equal to the return on equity, given by the corporate finance accounting relation:

$$
\frac{I_{t+1}^{c}}{K_{t}}-\delta=\frac{E_{t+1}-E_{t}}{E_{t}}=\pi_{t}+\left(\pi_{t}-r_{\max }\right) \frac{x_{\max }}{1-x_{\max }}
$$

The return on equity depends on the return on capital $\pi_{t}$ and it is an increasing function of the maximal debt/equity ratio $x_{\max } /\left(1-x_{\max }\right)$ allowed by banks, as long as the maximal cost of debt $r_{\max }$ is lower than the return on capital $\pi_{t}$. This is always the case with credit rationing, where credit demand exceeds credit supply. The corporate finance accounting relation determines the distribution of capital income $\pi_{t}$ between lenders $\left(r_{\max }\right)$ and equity-owners $\left(\left(E_{t+1}-E_{t}\right) / E_{t}\right)$. This financially constrained capital growth model has been used in partial equilibrium along with the assumption of the increasing cost of growth of the firm (Penrose effect), but without demand effects (Chatelain [1998]), adapted for econometric estimation (Chatelain [2000]) and estimated on French data by Chatelain and Teurlai [2006] and more broadly on European data by Chatelain et alii [2003]. It has also been used in a profit driven growth model (Amable, Chatelain, Ralf [2004]).

\subsection{Solving the model}

Aggregate demand on date $t$ is given by:

$$
Y_{t}^{d}=G_{t}+b C_{t-1}+c \min \left(Y_{t}^{d}, Y_{t}^{c}\right)+\min \left(I_{t}^{c},(n+\delta-a) K_{t-1}+a k Y_{t}^{d}\right)
$$

Aggregate demand takes four different values depending on the four possible regimes: demand driven (or wage led) output and investment denoted $D D\left(Y_{t}=Y_{t}^{d} ; I_{t}=I_{t}^{d}\right)$, profit led (capacity constrained) output and investment facing financial constraints denoted $C C\left(Y_{t}=Y_{t}^{c} ; I_{t}=I_{t}^{c}\right)$ and two mixed regimes where output is demand driven (or wage led) and investment financially constrained denoted $D C\left(Y_{t}=Y_{t}^{d} ; I_{t}=I_{t}^{c}\right)$, or where output is profit led and investment is demand led $C D\left(Y_{t}=Y_{t}^{c} ; I_{t}=I_{t}^{d}\right)$ :

$$
\begin{aligned}
Y_{t}^{d}[D C] & =\frac{1}{1-c}\left(G_{t}+b C_{t-1}+I_{t}^{c}\right) \\
Y_{t}^{d}[D D] & =\frac{1}{1-c-a k}\left(G_{t}+b C_{t-1}+(n+\delta-a) K_{t-1}\right) \\
Y_{t}^{d}[C D] & =\frac{1}{1-a k}\left(G_{t}+b C_{t-1}+c Y_{t}^{c}+(n+\delta-a) K_{t-1}\right) \\
Y_{t}^{d}[C C] & =G_{t}+b C_{t-1}+c Y_{t}^{c}+I_{t}^{c}
\end{aligned}
$$

Aggregate demand at date $t$ is computed as the minimum of aggregate demand in each of the four possible regimes: 


$$
Y_{t}^{d}=\min \left(Y_{t}^{d}[D C], Y_{t}^{d}[D D], Y_{t}^{d}[C D], Y_{t}^{d}[C C]\right)
$$

Knowing aggregate demand, one solves the model on date $t$ as a triangular system of equations following this order: aggregate output, investment demand, constrained investment, aggregate investment, the unemployment rate, aggregate demand/capacities (cf. the degree of capacity utilization), the real wage, the profit rate, leverage and the credit interest rate are computed for the current period, as well as next period productive capacities necessary to start another iteration for the next period $t+1$.

\section{Dynamics following a Permanent Rise of Real Interest Rate and Economic Policy}

At the initial date, the economy is in a knife edge steady state equilibrium where the investment demand is equal to the financial investment frontier (a situation which may only happen by chance) and where demand is equal to productive capacities (appendix). A permanent rise of the real interest rate $r_{t}$ leads immediately to a binding financial constraint on investment. Then, the economy passes through several stages (see a simulation example on figure 1, following a permanent rise of $1 \%$ of the real interest rate). Economic policy decisions increasing output and decreasing unemployment are detailed in each stages.

Stage 1 (periods 2 to 6 of the simulation): Investment is financially constrained. In the short run, its fall leads to a larger fall of aggregate demand than the fall of the capacity of production. Hence, there is not yet a capital shortage. An increase of public expenditures has an effect on output due to a consumption multiplier effect:

$$
\frac{\partial Y_{t}^{d}}{\partial G_{t}}=\frac{1}{1-c}
$$

Supply side policies may also increase output, equal to aggregate demand, but with a one period lag $\left(z_{t}\right.$ represents the real interest rate $r_{t}$ (which should decrease to increase output) or the real wage $w_{t}$ (which should decrease) or the leverage ceiling $x_{\max }$ (which should rise)):

$$
\frac{\partial Y_{t+1}^{d}}{\partial z_{t}}=\frac{1}{1-c} \frac{\partial I_{t+1}^{c}}{\partial z_{t}}
$$

Business cycle analysts found that, on average, a demand shock have an effect in the next quarter on output, whereas a shock on monetary policy interest rate have an effect on output after 4 to 8 quarters.

Stage 2 (Period 7 of the simulation): As the financial constraint persists, productive capacities turn to be lower than aggregate demand. The degree of capacity utilization decreases, which decreases the profit rate. This effect on the profit rate may 
be partially offset because the firm also increases its markup as there is an increase of excess demand. Meanwhile, on the labor market, unemployment rises due to capital shortage. This may lead to a decrease of the nominal wage which could offset the (already mentioned) increase in output price due to the increase of excess demand. If this is the case, the real wage decreases and the rate of profit would start to increase after its fall. These movements of the rate of profit have been observed in Europe: a fall in the seventies followed by a rise to unprecedented levels in the eighties. This increase of profit may then relax the credit constraint and increase investment and aggregate demand.

Supply side policies increase output when the economy faces both a financial constraint on investment and a capital shortage on output, with a one period lag. A decrease of real interest rates, a decrease of real wage or a rise of the leverage ceiling increases retained profits which increases financially constrained investment on date $t$, which increases capacity constrained output only on date $t+1$, due to the time to build effect.

$$
\frac{\partial Y_{t+1}^{c}}{\partial r_{t}}=\frac{1}{k} \frac{\partial I_{t+1}^{c}}{\partial r_{t}}
$$

Government has to wait one period to observe the effect of financial supply side policies on output.

Stage 3 (Period 8 till the end of the simulation): Then, investment is no longer constrained, so that investment demand boosts aggregate demand. But capital shortage persists because of the adjustment delays on the stock of capital measured by the adjustment parameter $a$ (the Penrose effect [1959]). In this regime, there is no effects of financial supply side policies and the public expenditure multiplier is smaller that in stage 1 and stage 2 :

$$
\frac{\partial Y_{t}^{c}}{\partial G_{t}}=a \frac{\partial Y_{t}^{d}}{\partial G_{t}}=\frac{a}{1-a k}
$$

Stage 4: In the long run, another steady state equilibrium is reached. The gap between the financial frontier on capital growth and the steady state capital growth may increase as the firm benefits from a persistent increase of the profit share that she uses to reduce her debt and her weighted average cost of capital instead of using these additional earnings for investment. This behavior has been observed for large firms in the early 1990s in Europe in a context of high real interest rate and depressed demand.

This sequel may describe some of the dynamics related to output, unemployment, investment and the profit rate which occurred in large countries of continental Europe (for example, France and Germany) in the 1970s following the rise of real wages after the first oil shock, in the early 1980s, following the rise of real interest rates targeting a reduction of inflation in the United States of America and in Europe, and in the early 1990s, following the rise of real interest rates related to German reunification shock 
and the european monetary system exchange rate mechanism (see also Villa [2004]). However, those effects are likely to have been contaminated by pro-cyclical relative falls of government expenditures related to budget deficits constraints originated by exchange rate pegs, the Maastricht criteria and the Stability and Growth pact. This type of shock is studied in the following section.

\section{Dynamics following a Permanent Fall of Public Expendi- tures and Economic Policy}

This section considers the dynamics of the economy after a $10 \%$ permanent fall of public expenditures. Starting from the same initial situation before the shock than in the previous section, the economy faces excess capacities (hence a decrease of the profit rate) and unconstrained investment (figure 2). Unconstrained investment is below the warranted growth rate, because its aims at reducing excess capacities. A binding financial constraint remains unlikely even with the decline of the profit rate related to the decline of capacity utilization. This leads to an adjustment to a lower output equilibrium where the capacity utilization rate returns to its equilibrium, equal to one in this simple model. If one adds a negative effect of unemployment on the real wage, the profit rate may have increased in the new steady state equilibrium. This increase of the profit rate lead to a steady decrease of leverage, which widens the gap between the capital growth financial frontier and the steady state growth of capital, as in stage 4 of the previous section. As written in that section, this increase of profits used to reduce debt instead of investing has been observed for large firms in the early 1990s in Europe.

In this regime, Keynesian policies have a strong effect on output. The multiplier effect of public expenditures $G_{t}$ depends on both the propensity to consume and the propensity to invest in a context of insufficient capacities.

$$
\frac{\partial Y_{t}^{d}}{\partial G_{t}}=\frac{1}{1-c-a k}
$$

Supply side policies are not recommended as they have no effect on output.

\section{Conclusion}

This model analyzed how capital shortage and financial constraint may evolve at different pace for a growing economy shocked by a rise in interest rates or a fall of public expenditures. A key feature is that the profit rate depends on the degree of capacity utilization and on unemployment, so that the financial frontier on capital growth is endogenous. We reached two conclusions.

First, following a rise of real interest rate, the fact that investment is a component of aggregate demand suggests a fine tuning with respect to Keynesian policies and 
financial supply side policies (decrease of real interest rate or of the real wage, increase of the leverage ceiling).

- Keynesian policies increase output immediately after the shock, because aggregate investment depressed aggregate demand, and, to a lesser extent, following the start of a financial recovery, as a rise in aggregate demand may boost unconstrained investment in order to speed up the adjustment of insufficient capacities of production.

- On the other hand, financial supply side policies increase output only later on, after this kind of shock. They demand more time to increase output and unemployment, because they increase retained earnings which increase investment which increase productive capacities and employment only after a while.

Second, after a negative demand shock, Keynesian policies increase output because they stimulate both consumption and investment. On the other hand, financial supply side policies have no effect on output.

Indeed, some supply and demand shocks turned to be simultaneous, due to European deficit constraints limiting counter-cyclical policies, instead of promoting a coordinated European rise of public investment and/or expenditures. Real economies include time-varying proportions of financially constrained firms and capacity constrained firms. The diagnosis on efficient economic policies has to be weighted by these proportions.

Further research may consider first an economy with stock markets and wealth effects of equity prices along the lines proposed by Lavoie and Godley (2001-2002) and Villa (2004). Second, government debt may face that households are not always willing to allocate their savings first in government bond. Third, the value of banks' loans may differ from the value of its deposits. Fourth, an extension may deal with the nominal effects of inflation, before finally estimating the model using data from European economies.

\section{References}

[1] Alexiou, C. (2001): 'Crafting a Post Keynesian macroeconomic framework to explain European unemployment: econometric evidence form the European Union countries', Journal of Post Keynesian Economics, 24(1), pp. 59-80.

[2] Alexiou, C., Pitelis C. (2003): 'On Capital Shortages and European unemployment: a panel data investigation', Journal of Post Keynesian Economics, 25(4), pp. 613-640.

[3] Arestis, P., Baddeley, M., Sawyer, M. (2007): The relationship between capital stock, unemployment and wages in nine EMU countries, Bulletin of Economic Research, 59(2), pp. 125-139.

[4] Amable, B., Chatelain J.B., Ralf K. (2004): 'Credit Rationing, Profit Accumulation and Economic Growth', Economics Letters, 85(3), pp.301-307. 
[5] Chatelain, J.B. (1998): 'Investment facing Credit Rationing', The Manchester School, 66(S), pp. 102-115.

[6] Chatelain, J.B. (2000): 'Explicit Lagrange Multiplier for Firms Facing a Debt Ceiling Constraint', Economics Letters. 67(2), pp. 153-158.

[7] Chatelain, J.B. (2001): 'Mark-up and Capital Structure of the Firm Facing Uncertainty', Economics Letters, 74(1), pp. 99-105.

[8] Chatelain, J.B., Ehrmann M., Generale A., Martínez-Pagés J., Vermeulen P., Worms A. (2003): 'Monetary policy transmission in the euro area - Evidence from micro data on Banks and Firms.' Journal of the European Economic Association, 1(3), pp. 731-742.

[9] Chatelain, J.B., and Teurlai J.C. (2006): 'Euler Investment Equation, Leverage and Cash Flow Misspecification: an Empirical Analysis on a Panel of French Manufacturing Firms.' Journal of Macroeconomics, 28(2), pp.361-374.

[10] Dos Santos, C.H. (2005): 'A stock-flow consistent general framework for formal minskyan analyses of closed economies', Journal of Post-Keynesian Economics, 27(4), pp. 712-735.

[11] Dos Santos, C.H. (2006): 'Keynesian theorizing during hard times: Stock-flow consistent models as an unexplored frontier of Keynesian macroeconomics', Cambridge Journal of Economics, 30(4), pp. 541-565.

[12] Dos Santos, C.H., Zezza, G., (2004): 'The role of monetary policy in postkeynesian stock-flow consistent macroeconomic growth models: Preliminary results', Lavoie M. (ed.), Central Banking in the Modern World: Alternative Perspectives, pp. 183-208, Edward Elgar, Cheltenham

[13] Dos Santos C.H., Zezza G. (2006): 'Distribution and growth in a post-keynesian stock-flow consistent model', Salvadori N. (ed.), Economic Growth and Distribution. On the Nature and Causes of the Wealth of Nations, pp. 100-123, Edward Elgar, Cheltenham.

[14] Dos Santos C.H., Zezza G. (2008): 'A Simplified, Benchmark, Stock-Flow Consistent Post-Keynesian Growth Model', Metroeconomica, 59(3), pp. 441-478.

[15] Foley, D., Taylor, L. (2006): 'A Heterodox Growth and Distribution Model', Salvadori N. (ed.): Economic growth and distribution: on the nature and causes of the wealth of nations, pp. 75-99, Edward Elgar Publishing, Cheltenham.

[16] Godley, W., Lavoie, M. (2007): Monetary Economics: An Integrated Approach to Credit, Money, Income, Production and Wealth, Palgrave Macmillan, Houndmills. 
[17] Hein, E. (2007): Interest rate, debt, distribution and capital accumulation in a post-Kaleckian model, Metroeconomica, 57, pp. 310-339.

[18] Lavoie, M. (2004): L'économie postkeynésienne, La Découverte. Paris.

[19] Lavoie, M. Godley W. (2001-2002): 'Kaleckian models of growth in a coherent stock-flow monetary framework: a Kaldorian view', Journal of Post Keynesian Economics, 24 (2), pp. 101-135.

[20] Le Heron, E., Mouakil T. (2008): 'A Post-Keynesian Stock Flow Consistent Model for Dynamic Analysis of Monetary Policy Shock on banking behaviour', Metroeconomica, 59 (3), pp. 405-440.

[21] Penrose, E. (1959): The theory of the Growth of the Firm, Basil Blackwell, Oxford.

[22] Shaikh, A. (2009): 'Economic policy in a growth context: a classical synthesis of Keynes and Harrod', Metroeconomica, 60 (3), pp.455-494.

[23] Skott, P. (2008): 'Theoretical and empirical shortcomings of the Kaleckian investment function', Working Paper 2008-11, University of Massachusetts, Amherst.

[24] Taylor, L. (2004): Reconstructing Macroeconomics, Harvard University Press, Cambridge, Massachusetts

[25] Treeck van, T. (2008): 'Reconsidering the Investment-Profit Nexus in FinanceLed Economies: an ARDL-Based Approach', Metroeconomica, 59(3), pp. 371-404.

[26] Villa, P. (2004): 'Croissance et régimes d'investissement', Document de travail 2004-01, Cepii.

[27] Wood, A. (1975): A Theory of Profits, Cambridge University Press, Cambridge.

\section{Appendix}

Numerical values for the simulation: $k=1.5, q=1, \delta=10 \%, b=0.5, c=0.3453$, $r_{\max }=2 \%, x_{\max }=40 \%, x_{\min }=30 \%, \phi=0.1$ (hence $r_{0}=1 \%$ ), $K_{0}=6000=$ $(1+n) K_{-1}=(1+n) k Y_{0}$. Then debt is $B_{0}=x_{\max } K_{0}=2400$ and equity is $E_{0}=$ $K_{0}-B_{0}=3600$. We start from a steady state equilibrium on the goods market $(U C=$ 1) and on the labor market $\left(U R_{0}=0\right)$, and a particular situation where investment demand is equal to the financial frontier on investment $\left(I_{0}^{c}=I_{0}^{d}\right)$ in this steady state. Hence, $n=\pi_{0}+\left(\pi_{0}-r\right) \frac{x_{\max }}{1-x_{\max }}=4 \%$ implies a profit rate after depreciation $\pi_{0}=$ $3.2 \%$, with a value before depreciation $\pi_{0}+\delta=\left(1-\frac{w_{0}}{q}\right) \frac{1}{k}$ so that the real wage is $w_{0}=0.802$ which corresponds to a positive markup. Labor, aggregate demand and 
its components are growing at the warranted growth rate in the steady state, with the following initial values:

$$
\begin{aligned}
Y_{0}^{c} & =Y_{0}^{d}=L_{0}^{d}=L_{0}^{s}=\frac{K_{0}}{(1+n) k}=3846.15 \\
C_{0} & =\frac{c(1+n)}{(1+n-b)} Y_{0}=0.66502 \cdot Y_{0} \\
I_{0}^{c} & =I_{0}^{d}=n \frac{K_{0}}{1+n}+\delta \frac{K_{0}}{1+n}=(n k+\delta k) Y_{0}=(0.06+0.15) Y_{0}=0.21 \cdot Y_{0} \\
B_{0}-B_{-1} & =n x_{\max } \frac{K_{0}}{1+n}=n x_{\max } k Y_{0}=0.024 \cdot Y_{0} \\
E_{0}-E_{-1} & =n\left(1-x_{\max }\right) \frac{K_{0}}{1+n}=n\left(1-x_{\max }\right) k Y_{0}=0.048 \cdot Y_{0} \\
r_{\max } B_{-1} & =x_{\max } \frac{K_{0}}{1+n}=r_{\max } x_{\max } k Y_{0}=0.012 \cdot Y_{0} \\
\left(\pi_{0}+\delta\right) K_{-1} & =E_{0}-E_{-1}+\delta K_{-1}=0.198 \cdot Y_{0} \Rightarrow \pi_{0}+\delta=0.198 \cdot \frac{Y_{0}}{K_{-1}}=13.2 \% \\
W_{0} L_{0} & =\left[1-\left(\pi_{0}+\delta\right) k\right] Y_{0}=(1-0.198) Y_{0}=0.802 \cdot Y_{0} \\
G_{0} & =Y_{0}-C_{0}-I_{0}=\left(1-\frac{c(1+n)}{(1+n-b)}-(n+\delta) k\right) Y_{0}=0.12498 \cdot Y_{0} \\
G_{0} & =\left(\frac{n-r_{0}}{1+n}\right) B_{0}^{g} \Rightarrow B_{0}^{g}=\left(\frac{1+0.04}{0.04-0.01}\right) 0.12498 \cdot Y_{0}=4.3326 \cdot Y_{0} \\
B_{0}^{g} & =\left(\frac{n}{1+n}\right) B_{0}^{g}=\left(\frac{n}{n-r_{0}}\right) G_{0}=\frac{0.04}{0.03} 0.12498 \cdot Y_{0}=0.16664 \cdot Y_{0} \\
B_{0}^{g} \frac{B_{0}^{g}}{1+n} & =\left(\frac{r_{0}}{1+n}\right) B_{0}^{g}=\left(\frac{r_{0}}{n-r_{0}}\right) G_{0}=\frac{0.01}{0.03} 0.12498 \cdot Y_{0}=0.04166 \cdot Y_{0}
\end{aligned}
$$

Table 4: Transaction matrix steady state date $t=0$, in percentage of output $Y_{0}$

\begin{tabular}{|l|l|l|l|l|}
\hline$\% Y_{0}$ & Households-Banks & Firms-Capitalists & Govt & Total \\
\hline Consumption & $-C_{t}=-0.665$ & $C_{t}=\frac{c(1+n)}{(1+n-b)}=0.665$ & & 0 \\
\hline Govt & & $G_{t}=Y_{t}-C_{t}-I_{t}=0.125$ & $-G_{t}$ & 0 \\
\hline Investment & & $I_{t}=n k+\delta k=0.06+0.15=0.21$ & & 0.21 \\
\hline Wages & $W_{t} L_{t}=0.802$ & $-W_{t} L_{t}=-0.802$ & & 0 \\
\hline Depreciation & & $-\delta k=-0.15$ & & -0.15 \\
\hline Interest Credit & $r_{t-1} B_{t-1}=0.012$ & $-r_{t-1} B_{t-1}=-0.012$ & & 0 \\
\hline Interest Bonds & $r_{0} B_{t-1}^{g}=0.041$ & & $-r_{0} B_{t-1}^{g}$ & 0 \\
\hline Total: Savings & $\begin{array}{c}\Delta B=0.024+ \\
\Delta B^{g}=0.166\end{array}$ & $=\Delta E=0.048$ & $=-\Delta B^{g}$ & 0.06 \\
\hline
\end{tabular}

The adjustment parameters are chosen as: $a=0.25, a_{1}=0.2<a_{2}=0.4$. 